\title{
A UNIVERSITY COURSE IN ARTS AND SCIENCE
}

$\mathrm{T}$ HE General Board of the Faculties of the University of Cambridge has prepared a report outlining a course whereby students could undertake study of a science subject as well as of an arts subject. At present no firm recommendations have been made to the University ; none will be made by the General Board until the Senate has had the opportunity of discussing the important new questions of educational policy raised by the proposals.

The case for a new university course combining science and arts subjects is persuasively argued in the report. It is well known that a large number of graduates do not make direct use, after they leave their university, of the specialized knowledge they have acquired during their undergraduate days. For many such students it is the nature of the education they receive at the university, rather than the content of their courses, which is important; in the wide range of posts which they may be expected to occupy in national and local government, industry and other fields, the factual knowledge which they have acquired at the university will be of less value than the way in which they have been trained to think. The Board considers that although the majority of such non-specialist students will continue to profit from existing courses either in the arts or in the sciences, there are others who would benefit greatly from an opportunity to study both an arts subject and a science subject at the university.

The new course would give students the advantages of training in both arts and science. Arts men are trained not only to collect accurate data and to use them systematically, but also to exercise critical judgment upon matters of opinion where scholars may reach quite different conclusions. On the other hand, the conclusions of the scientist are based on precise observations and measurements, involve exact calculations, and must be tested by experiment or controlled observation; agreement on essential issues ean therefore ultimately be reached. With this distinction in mind, the Board thinks the time is opportune for a new scheme, within the Cambridge Tripos system, designed to give undergraduates an opportunity of undergoing both types of discipline, and of learning to appreciate the advantages and limitations of both. The purpose of the scheme is to provide a course that is specially planned for the undergraduate who knows at the outset of his university career that he does not wish to specialize in science, but who nevertheless wishes to gain a measure of insight into the aims and methods of science.

Although the Board's recommendations are based primarily on the scholarly and intellectual merits of the proposed combination of arts and science subjects, it considers that such a combination would have other, secondary, advantages. Those who took the course as a preparation for an administrative career in which they would most probably have to deal with specialist scientists and to make judgments on scientific matters would be better equipped for their work through having made some study both of the humanities and of scientific method and thought. If Cambridge were to provide the kind of course recommended, it might encourage some schools to establish corresponding combined courses in their sixth forms.

'The course recommended by the Board would include one specially designed in science, extending over three terms and the preceding long vacation, which could either precede or follow a two-year course for a part of an existing Tripos in an arts subject. In making this suggestion, the Board emphasizes that it considers it to be the most practicable suggestion at the present time, and not necessarily the ideal course or the only course that might eventually be adopted by the University. It also emphasizes that the proposed course is not intended to train persons who could in any way be regarded as substitutes for qualified scientists. The Board realizes that, at the present time, when the demand for trained scientists is constantly increasing, most of those who have specialized in scientific subjects at school will not wish to take a course com. bining arts and science. It has based its reasoning on the assumption that the greatest need is likely to be for a course in science specially designed for those who have studied arts subjects at school.

Since the aim of the specially designed course would be to teach science as part of a general education, the emphasis would be on those aspects of science which were of importance to students who did not intend to become practising scientists; the parts of science to be particularly stressed should be concerned with methods of thought which are, so far as possible, different from those used in the humanities.

The course would be planned to study a comparatively narrow branch of science in considerable depth in such a way as to bring out the intellectual content of the subject. The acquisition of some detailed scientific knowledge would be second in importance to learning about the methods of investigation and the methods of thought employed in science. The subject selected for study should be a branch of science which is advancing at the present day and which has wide applications. Researches in it should have been in progress long enough for interesting lessons to be drawn from studying its advances. It should involve some exacting processes of thought, if possible with wider philosophical implications ; mathematics should be used little in its presentation.

To begin with, the course recommended is one dealing with radioactivity and the atomic nucleus; a course of lectures lasting one academic year, together with a preliminary course of five and a half weeks in the preceding long vacation, could be so planned as to provide a scholarly study of that branch of physics suitable for undergraduates who had obtained honours in an arts Tripos, and leading up to an examination at honours level. The Board hopes that it may eventually be possible to institute a course illustrating the aims and methods of the biological sciences, possibly on some such topic as 'evolution', which would range over several fundamental sciences.

The Board has considered whether some kind of qualifying examination should be held at any early stage of the science course so as to ensure that the 
course would only be taken by students who were likely to be able to cope with it; it believes that it would be impracticable to set a formal examination soon enough to fulfil this purpose, but it should be possible for the persons responsible for the teaching for the course to devise tests which would enable them to advise tutors at the end of the proposed preliminary long vacation course whether their students were likely to complete the full course satisfactorily.

Practical classes designed to teach techniques to future specialist scientists would not be appropriate in this kind of course. Instead there would be lecture demonstration experiments designed to exhibit phenomena, and whenever possible the students would be encouraged to manipulate these themselves, and sometimes to take numerical readings for the purpose of demonstrating some quantitative law. A few simple quantitative experiments would be performed by the students, and they would be asked to explain the results. The emphasis would be on the explanation and not on the taking of the observations. The total time spent on practical work would be comparatively small.

The proposed course would be of honours standard; students of good quality should be attracted to the course so that potential employers shall be persuaded that the course is a serious one and not a 'soft option'. To this end the Board proposes that the examination to be held at the end of the proposed one-year course in science should be a Tripos examination; any other name would predestine the experiment to failure.

The Board considers that the teaching for the proposed course should be given by experienced University teaching officers from the appropriate department who are actively engaged in work in their own subject and who wish to take part in this particular experiment; some or all of the normal teaching programme of those who take part in the proposed special course should be taken over by one or more University demonstrators who would be specially appointed for this purpose.

\section{VEGETABLE QUALITY}

$T$ HE Second International Colloquium on Vegetable Quality was held in the Conservatoire des Arts et Métiers, Paris, during April 24-27. It was organized under the auspices of the Confoederatio Internationalis ad Qualitates Plantarum Edulium Perquirendas, the membership of which comprises those interested in the genetics, biochemistry, physiology, ecology, culture and preparation of edible, and medicinally used, plants. The first colloquium, which had been held in Geisenheim am Rhein in 1955, had not attracted such an international interest as the second colloquium, which had an attendarice of about one hundred specialists, including German, Italian, Polish, Russian, British and American workers.

After the visitors had been welcomed by Profs. E. Terroine and J. Dufrénoy (Paris) and Prof. L. Genevois (Bordeaux), Prof. W. Schuphan (Geisen. heim) opened the colloquium and outlined the various fields of study of vegetable quality. Quality is the sum of the biochemical properties of the plant and may conveniently be classified under the three headings of external features, suitability, and nutritional factors. Prof. Schuphan stressed the importance of obtaining a correlation between the biological values of nutritionally important compounds and their chemical analyses. The life and work of Prof. A. Scheunert, former director of the Vitamin Institute at Potsdam.Rehbrücke, was commemorated by Prof. Schuphan, while an address on Prof. A. Chevalier, founder of the Colonial Agronomy Laboratory of the Museum of Natural History, was delivered by Prof. M. Portères, the present director of the Laboratory.

Forty-eight papers were presented. As it is not possible to summarize all adequately, an attempt will be made to present an impression of the general trends in the various sessions.

Since vegetable protein is the major protein intake in the unsophisticated diets of the bulk of the world population, it was natural that in the session on proteins and amino-acids the major concern should be with nutritional quality, especially with regard to content of essential amino-acids, of vegetable protein. Prof. Schuphan presented two papers on the analysis of essential amino-acids in the Brassica family and the influence of genetical factors on the amino-acid composition; ten different Brassica spp. show a wide range of biological activities. Dr. W. Postel (Geisenheim), in a paper on the effect of manuring on the essential amino-acid composition of potatoes, showed that, above an optimal concentration of nitrogen in the soil, there was a decrease in the biological activity of the protein in the potato; it was suggested in discussion that this may have been caused by a lack of carbon for synthesis of these amino-acids. Dr. V. L. Kretovitch (Bach Institute, Moscow) described his work on the biosynthesis of amino-acids in plants, most of which are synthesized by transamination of the appropriate keto-acids. However, tryptophan synthesis is stimulated by the addition of indole, serine and anthranilic acid. Asparagine and glutamine are apparently formed directly in the protein by amination of aspartic and glutamic acids, respectively. Mlle. M. L. Champigny (Gif) discussed the formation of amino-acids during photosynthesis in Crassulaceae. Aspartic and glutamic acids and alanine, which are derived from Krebs cycle keto. acids, are formed first. However, on long exposures to light the alanine concentration diminishes and that of serine is increased. Mlle. Champigny also described how the amino-acid composition of Chlorella proteins varies according to whether urea or potassium nitrate is used as nitrogen source. Using potassium nitrate as compared with urea increases the concentrations of aspartic and glutamic acids but the concentrations of serine and glycine decrease. The microbiological determination of tyrosine, tryptophan, methionine and lysine directly in plant proteins was discussed by Prof. Genevois and Dr. J. Baraud (Bordeaux).

The session on vitamin $\mathrm{C}$ was devoted to discussions on the methods of determination of vitamin $\mathrm{C}$ and $\mathrm{a}$ comparison of the vitamin C content of both European and tropical seed and stone fruits, especially in relation to the satisfaction of nutritional requirements for vitamin $\mathrm{C}$ by such foods.

Two complementary papers on the biosynthesis of carotenoids were given by Dr. T. W. Goodwin (Liverpool) and Prof. G. Mackinney (Berkeley, California). Dr. Goodwin discussed mainly the structures and metabolism of compounds which might be precursors of the $\mathrm{C}_{5}$-repeating unit which is the basis of the $\mathrm{C}_{40}$-skeleton of the carotenoids. The 